\title{
The health risk of the agricultural production in potentially contaminated sites: an environmental-health risk analysis
}

\author{
Giovanni Russo, Giuseppe Verdiani \\ Department of Agro - Environmental Sciences (DISAAT), University of Bari, Italy
}

\begin{abstract}
Rural areas are often interested by pollution phenomena generated by agricultural activities with a high use of pesticides and/or by anthropic activities, such as industrial plants or illegal waste disposal sites, which may cause even long-range contamination. The risk for human health from the pollutants present in the environment can be quantitatively evaluated by the environmental health risk analysis set out in the Italian Legislative Decree no. 152/2006 (Italian Regulation, 2006). This analysis is the best technical-normative tool to estimate the health risks linked to the pollutants present in the environment but it does not consider the specificity of agricultural soils or the contamination of agricultural products.

This study aims to provide this missing technical-normative data by identifying and applying a suitable methodology to evaluate the health risk caused by the ingestion of agricultural products grown in contaminated soils. The risk analysis was applied to two contaminated areas in southern Italy using an innovative methodology based on widely accepted parameters for the determination of polycyclic aromatic hydrocarbons (PAHs) soil-plant bio-transfer factor in the case of horticultural crops. In addition, some concentration limits of PAHs in agricultural soils are proposed that may be of help to the competent authorities (health agencies, local authorities) in delineating the areas requiring strict health surveillance of the food products cultivated.
\end{abstract}

Correspondence: Giuseppe Verdiani, Department of Agro - Environmental Sciences (DISAAT), University of Bari, via Amendola 165/A 70126 Bari, Italy. Tel/Fax: +39.3404619902. E-mail: giuseppeverdiani@hotmail.it

Key words: agricultural soils, health risk, pollution.

Contributions: the authors contributed equally.

Received for publication: 18 May 2012.

Accepted for publication: 29 August 2012.

(C) Copyright G. Russo and G. Verdiani., 2012

Licensee PAGEPress, Italy

Journal of Agricultural Engineering 2012; XLIII:e15

doi:10.4081/jae.2012.e15

This article is distributed under the terms of the Creative Common Attribution Noncommercial License (by-nc 3.0) which permits any noncommercial use, distribution, and reproduction in any medium, provided the original author(s) and source are credited.

\section{Introduction}

Rural areas may be interested by the presence of polluting substances that may compromise the chemical-physical and microbiological quality of the environment and of the food products cultivated there. In fact, some pollutants accumulate and remain in the soil for long periods of time, are absorbed by the plants and then transferred to the food chain with potential risks for human health (Pasetto et al., 2007; Petruzzelli and Pedron, 2007; Violante et al., 2007).

The transfer of organic and inorganic pollutants from the environment to agricultural products occurs through the absorption by leaves and roots (Sharma and Tripathi, 2009) and subsequent translocation via xylem transport (Bell, 1992; Environment Agency, 2006).

The high lipid content of plant tissues determines the absorption and bioaccumulation of lipophilic organic pollutants (ARPA Puglia, 2010a and 2010b), such as polycyclic aromatic hydrocarbons (PAHs), polychlorinated biphenyls and organochlorine pesticides. The primary modality of human exposure to PAHs is the consumption of contaminated agricultural products (Khillare et al., 2012). This exposure can cause cancers of lung, respiratory system, urinary tract and bladder (Bosetti et al., 2007). There is a confirmed link between diet, exposure to PAHs and the different forms of cancer (Lee and Shim, 2007; Yoon et al., 2007).

Heavy metal absorption and bioaccumulation in plant species occurs through the root apex and is strongly related to their bioavailability and the chemical-physical characteristics of the soil (D'Aprile, 2006). The primary means of human exposure to heavy metals is their intake with food (Scharma et al., 2008). This may cause adverse health effects, such as cardiovascular and nervous system diseases (IPCS INCHEM, 1992).

At present, there are no standards for health risk assessment related to agricultural environment pollution (Beccaloni et al., 2010).

The methodology used for health and environmental risk analysis is regulated by the Italian Legislative Decree no. 152/2006 (Italian Regulation, 2006) and can be integrated in order to assess the human health risk associated with ingestion of agricultural products grown in polluted areas (Russo and Verdiani, 2012).

The health and environmental risk analysis is, in fact, an advanced procedure for the quantitative assessment of the risks related to the presence of pollutants (Cicero and Scaini, 2010). This allows the identification of the threshold concentration of riskthat, if exceeded, determines that the site is contaminated. The use of health and environmental risk analysis, regulated by Italian Standards, is required when concentrations of pollutants in environmental matrices are above the threshold concentrations of contamination established by the Italian Legislative Decree no. 152/06, Table 1, Part IV, Annex 5 (Italian Regulation, 2006). These concentrations vary according to the use made of the sites and they are specifically differentiated into public or private green areas, residential areas (part A of Table 1, Italian Regulation, 2006) or industrial sites (part B of that Table, Italian 
Regulation, 2006). Agricultural sites are not explicitly indicated in the Italian Legislative Decree no. 152/06. In these areas, the presence of pollutants with concentrations higher than threshold valuesfor green areas requires a specific analysis of the environmental health risk. The health risk from the contaminated sites is strictly linked to the contaminated environmental compartments (superficial soil, deep soil or groundwater), to the chemical-physical and toxicological properties of the pollutants, to the pollutants' transport mechanism and to the contamination targets (adults, children, ecosystems) (Cheng and Nathanail, 2009; ISPRA, 2008).

The health risk evaluation is based on the construction of the conceptual model of the site (CMS) (ISPRA, 2008) explaining the relationshipsbetween contamination sources, migrations routes, means of exposure and targets (Figure 1).

The development of the CMS is, therefore, based on the identification and parameters of three elements:

- sources of contamination;

- routes of migration;

- ways in which humans are exposed near the contaminated site (on site) or outside it (off site).

The sources of contamination must be characterised by evaluating the hydro-geological and geometrical characteristics of the site and by identifying the representative concentration values of the pollutants.

The polluting substances, however, reach the human receptors by different routes of migration (soil, air, water) and are subject to attenuation phenomena. The pollutant concentration at the exposuresite can be evaluated by means of the mathematic modelling of their transport (Timidei and Riganti, 2009).

Health risk is evaluated according to the pollutant concentration, the contamination target (Figure 1) and the means of exposure (inhalation, dermal contact and ingestion).

For this purpose, seventeen commercial software and freeware packages have been developed for the risk analysis (Cheng and Nathanail, 2009; Di Sante et al., 2009). These were often based on the risk-based corrective action approach elaborated by the American Society for Testing and Materials (ASTM) and acknowledged in Italy in the 2002 handbook of the Association for Unification in the Industrial Chemical Sector (UNICHIM) no. 196 Part I.

The currently available methodologies for risk analysis do not specifically consider polluted agricultural areas where the primary means of human exposure to pollutants is linked to the ingestion of food products (Cheng and Nathanail, 2009).

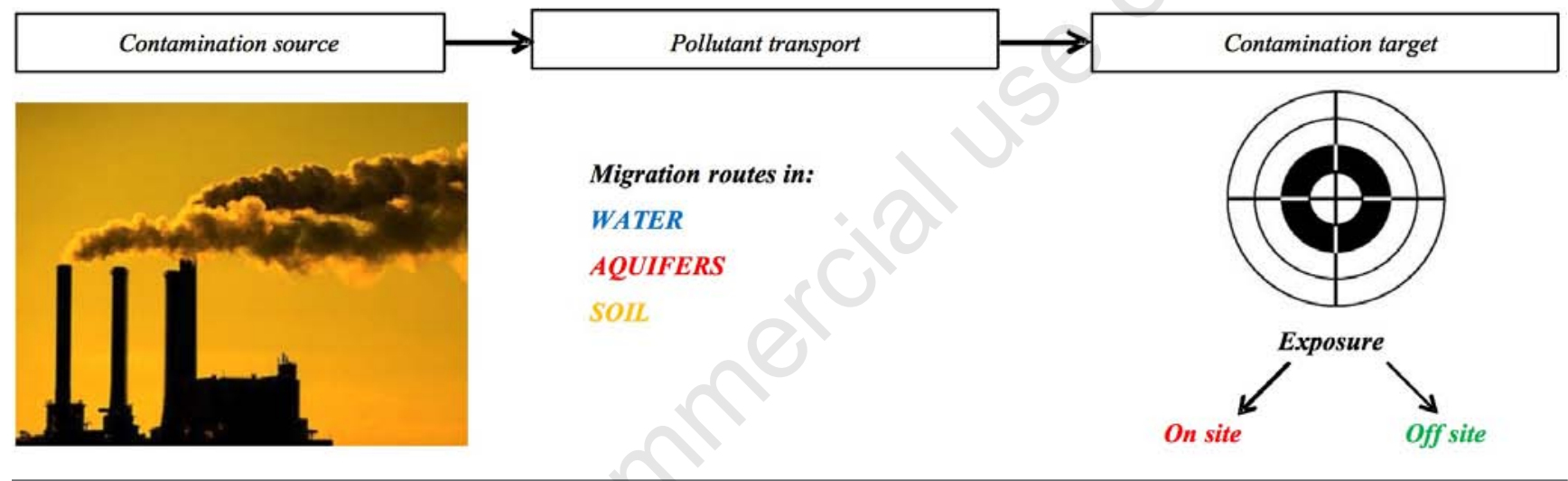

Figure 1. Conceptual model of the site.

Table 1. Steps of the risk analysis applied to the polluted agricultural areas.

Steps Organic pollutants Inorganic pollutants

1 Comparison between the soil pollutant concentrations and the threshold concentrations of contamination set in the Italian Legislative Decree no. 152/06 (Italian Regulation, 2006)

2 Determination of the soil-plant bio-transfer factors using the following models:

a) Trapp et al. (2007) for organic pollutants and potato;

b) Trapp (2007) for organic pollutants and fruit trees;

c) Trapp (2002) for organic pollutants and root vegetables;

d) Chiou et al. (2001) for organic pollutants and crops with known physiological characteristics;

e) Literature values for organic pollutants.

3 Assessment of pesticide concentration in the horticultural products and comparisons

with the limit concentrations set in the European

Regulation no. 396/05 (European Commission, 2005).

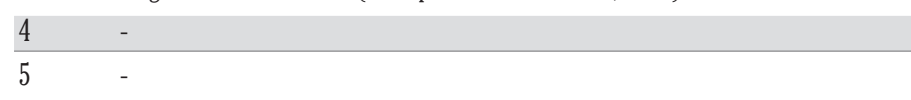

6 PAHs, polycyclic aromatic hydrocarbons; ADD, average daily dose; LADD, lifetime average daily dose; HQ, danger index; Rs, health risk.
Comparison between the soil pollutant concentrations and the threshold concentrations of contamination set in the Italian Legislative Decree no. 152/06 (Italian Regulation, 2006)

Determination of the soil-plant bio-transfer factors using the following models:

a) Travis and Arms (1988) for PAHs pollutants and horticultural crops; and carrot crops;

b) Thorn (2005) for inorganic pollutants;

c) Plant uptake model for inorganic pollutants (CRC Care, 2008);

d) Literature values for inorganic pollutants.

Assessment of pollutant concentration in the horticultural products.

Assessment of the polluter quantity daily assumed per head.

Calculation of the effective daily exposure range for the ADD toxic substances and the LADD carcinogenic substances. Calculation of the HQ and of the Rs.

[page 96] [Journal of Agricultural Engineering 2012; XLIII:e15] OPEN@ACCESS 
The evaluation of the health risk linked to the agricultural soils pollution should, therefore, be based on the correct estimation of: i) the concentration of pollutants in the agricultural products; and ii) the individual consumption of vegetables produced inside the contaminated area (Beccaloni et al., 2010).

The accurate modelling of the absorption of pollutants and bioaccumulation in plants is, therefore, essential in order to assess the contamination of agricultural products and the subsequent human exposure (Yang and Zhu, 2007). The role of vegetation in the transfer of chemical pollutants from the environment to specific plant tissues (stems, leaves, roots, fruit) has not yet been well characterised (McKone and Maddalena, 2007). The absorption and accumulation of pollutants varies from plant to plant (Brunetti et al., 2012) and is also strongly interconnected to soil and pollutant characteristics. In an attempt to predict the bioaccumulation of pollutants in plants, numerous models of root and/or leaf absorption of organic and inorganic substances have been developed.

There are many empirical, semi-empirical and mechanistic models available in the literature that allow the soil-plant bio-transfer factors for the organic pollutants to be determined (Topp et al., 1986; Ryan et al., 1988; Travis and Arms, 1988; McKone, 1993; Trapp and Matthies, 1995; Hung and Mackay, 1997; Chiou et al., 2001; Trapp, 2002; Trapp et al., 2003; Trapp et al., 2007). Most of these models have a general application while others are specific to potato and carrot crops (Trapp et al., 2007), fruit trees (Trapp, 2007) and root vegetables (Trapp, 2002). The bio-transfer models often require numerous input data related to the chemical-physical properties of the soil and plant physiological characteristics (Fryer and Collins, 2003). In the absence of specific data on the physiology of plant species, formulas that provide approximate biotransfer coefficients can be used.

The Travis and Arms (1988) relationship Eq. (1) is based on the noctanol/water partition coefficient $\left(\mathrm{K}_{\mathrm{ow}}\right)$ of organic pollutants. The organic pollutants' radical absorption is proportional to their noctanol/water partition coefficient (Paterson et al., 1994) that characterises the tendency to accumulate in plant tissues (Environment Agency, 2003). The link between bio-transfer factor and n-octanol/water partition coefficient has been observed, in particular for PAHs (Zohair et al., 2006). It was found that the application of the Travis and Arms (1988) formula provides similar results to those provided by crop specific models for potatoes, carrots and leafy vegetables (Kulháneka et al., 2005):

$$
\log T F=1.588-0.578 \log K_{O W}
$$

where TF [Adim. ( $\left.\mathrm{mg} \mathrm{kg}_{\text {aerial plant }}{ }^{-1}\right)\left(\mathrm{mg} \mathrm{kg}_{\text {soil }}{ }^{-1}\right)^{-1}$ ] is the pollutants' biotransfer factor from soil to vegetables, $K_{o w}$ is the n-octanol/water distribution coefficient of the polluting mixtures.

Eq. (1) cannot be used for the inorganic pollutants and, therefore, the bio-transfer factors shall be determined by consulting the bio-transfer data regarding specific pollutants, including all the possible chemical forms they can assume in the superficial soil or, alternatively, by the Thorn et al. model (2005):

$$
T F=\delta /\left(\theta w+r_{s} K d\right)
$$

where $\delta$ [adim.] is the ratio between the quantity of bio-available polluter and the total quantity in the soil, $\theta w$ is the soil porosity [adim.: $\left.\mathrm{cm}^{3} \times \mathrm{cm}^{-3}\right], r_{s}$ is the soil bulk density $\left[\mathrm{g} \mathrm{cm}^{-3}\right], K d$ is the soil/water repartition coefficient $\left[\mathrm{cm}^{3} \mathrm{~g}^{-1}\right]$.

A correct evaluation of soil-plant bio-transfer factor is needed in order to determine the concentration of pollutantsin agricultural products. The soil-plant bio-transfer factor can also help identify and define the threshold concentration of pollutants in the soil that would compromise the quality of food products.
The aim of this study was to develop a methodology to evaluate the individual risk linked to the consumption of vegetables grown in contaminated agricultural soils and to apply the proposed methodology to two contaminated sites in southern Italy.

This methodology has been applied, with appropriate adaptations, to determine the threshold concentrations of contamination of some PAHs in the agricultural soil.

Such evaluations may be useful for the authorities in charge of controlling horticultural products to verify the health and safety status and the consequent suitability of the agricultural products grown in areas interested by pollution phenomena for human consumption. The proposed procedure may also support rural planning in identifying and delimiting the soils in which the cultivation of food products is to be forbidden or regulated.

\section{Materials and methods}

\section{Methodology}

The health risk linked to the ingestion of vegetables grown in potentially contaminated agricultural soils was evaluated. The analysis is made up of three steps for the soils contaminated by pesticides and of three further steps for the soils contaminated by all the other categories of pollutants (Table 1).

\section{Step 1}

Analysis of the contaminated and examined soils aimed to identify those pollutants exceeding the threshold concentration of contamination established by the Italian Legislative no. 152/06 for the sites to be used as green areas (Italian Regulation, 2006).

\section{Step 2}

We determined the soil-plant bio-transfer factors for organic and inorganic pollutants that exceed the threshold concentration of contamination in the study areas.

In the present work, the soil-plant bio-transfer factors (TF) of organic pollutants have been determined through the use of the empirical model (Eq. 1) of Travis and Arms (1988) on the basis of the value of the coefficient $\mathrm{K}_{\mathrm{ow}}$ of each pollutant investigated. The $\mathrm{K}_{\mathrm{ow}}$ values are reported in the ISS/ISPESL databank (ISS/ISPESL, 2009a and 2009b) and represent a good indicator of the soil-plant bio-transfer potential (Dowdy and McKone, 1997) for PAHs pollutants and horticultural crops. This model was used because, in fact, the study area is used for horticultural cultivation and PAHs are present there.

The soil-plant bio-transfer factors of inorganic pollutants described in literature were used.

\section{Step 3}

We made a theoretical estimate of the concentration of pollutants in the agricultural products. The concentration of pollutants in the agricultural products was obtained by the relationship between them (Beccaloni et al., 2010):

$$
C_{v}=T F^{\prime} C_{\text {soil }} \times(1-0.12)\left[\mathrm{mg} \mathrm{kg}^{-1}\right]
$$

where $C_{v}\left[\mathrm{mg} \mathrm{kg}^{-1}\right]$ is the concentration of pollutants expressed in $\mathrm{mg}$ in $1 \mathrm{~kg}$ of edible vegetable, $T F$ is the bio-transfer factor [Adim.] i.e. relative error, $C_{\text {soil }}\left[\mathrm{mg} \mathrm{kg}^{-1}\right]$ is the concentration of pollutants expressed in $\mathrm{mg}$ in $1 \mathrm{~kg}$ of soil, and the constant value is a corrective factor based on the water content of the agricultural product under study ( $12 \%$ average relative humidity of the herbal products). For the agricultural soils contaminated by pesticides, the estimated concentration into the vegetables 
must be less than the limits established by the Regulation of the European Commission no. 396/05 regarding the maximum limits of pesticideresidues in or on food products (European Commission, 2005).

For the agricultural soils contaminated by polluting substances that are not categorised as pesticides, the methodology requires that the further three steps are carried out: steps 4, 5 and 6 .

\section{Step 4}

Estimates were made of the daily quantity of polluter assumed per head by ingestion of the vegetal products. The following equation (Beccaloni et al., 2010) wasused to determine the rate of daily contact with the polluting agents contained in food:

$$
\sum_{i}\left(C_{v} \times I R\right)_{i}\left[\frac{m g}{d}\right]
$$

where $I R\left[\mathrm{~kg} \mathrm{~d}^{-1}\right]$ is the consumption per head for each food category estimated by the National Institute of Research for Food and Nutrition (http://www.inran.it).

\section{Step 5}

The effective range of daily exposure for the average daily dose (ADD) of toxic substances and lifetime average daily dose (LADD) of carcinogenic substances has been calculated by the following equations (US EPA, 1997):

$$
\begin{aligned}
& A D D=\frac{\left[\sum\left(C_{v} \times I R\right)_{i} \times E F \times E D\right]}{(B W \times A T n)}\left[\frac{\mathrm{mg}}{\mathrm{kg} \cdot d}\right] \\
& L A D D=\frac{\left[\sum\left(C_{v} \times I R\right)_{i} \times E F \times E D\right]}{(B W \times A T c)}\left[\frac{\mathrm{mg}}{\mathrm{kg} \cdot \mathrm{d}}\right]
\end{aligned}
$$

Eqs. (5) and (6) represent the pollutant quantity in $\mathrm{mg}$, the consumers daily absorption by ingestion of agricultural products grown on contaminated soils:

$$
H Q=\frac{A D D}{R f D}[\text { Adim. }]
$$

where $E F\left[\mathrm{~d} \mathrm{y}^{-1}\right]$ is the exposition frequency, $E D[\mathrm{y}]$ the exposition duration, $B W[\mathrm{~kg}]$ the weight of the human receptors, $A T$ [d] the average time of exposition.

The frequency of exposition to contaminated food (EF) can be conservatively assumed to be 350 days/year (Beccaloni et al., 2010) if the consumer lives within the area of contaminated soil or with lower values for the off site consumers as, in this case, only a fraction of the consumed agricultural products comes from the contaminated area under evaluation. Exposition duration (ED) and the weight of the human receptors (BW) wereestablished at 24 years and $70 \mathrm{~kg}$ for adults and six years and $15 \mathrm{~kg}$ for children, respectively (ISPRA, 2008).

The ADD index [ $\mathrm{mg} \mathrm{kg}^{-1} \mathrm{~d}^{-1}$ ] concerns the toxic agents. Therefore, the average time of exposition to the toxic substances (ATn) contained in the food products grown in the contaminated sites has been established by the ISPRA at 8760 days for adults $\left(24 \mathrm{y} \times 365 \mathrm{~d} \mathrm{y}^{-1}\right)$ and 2190 for children (6 y $365 \mathrm{~d} \mathrm{y}^{-1}$ ) (ISPRA, 2008). The LADD index concerns the carcinogenic substances and, therefore, a time of exposition to these substances (ATc) of 2550 days $\left(70 \mathrm{y} \times 365 \mathrm{~d} \mathrm{y}^{-1}\right)$ has been considered (Beccaloni et al., 2010).

\section{Step 6}

The health risk associated with the exposure to pollutants contained in the vegetables for human consumption was analysed.

The health risk determined by the exposition to toxic pollutants is to be calculated as follows (ISPRA, 2008):

$$
H Q=\frac{A D D}{R f D}[\text { Adim. }]
$$

where $H Q$ is the danger index, $A D D$ the chronic effective exposition to the polluter, $R f D\left[\mathrm{mg} \mathrm{kg}^{-1} \mathrm{~d}^{-1}\right.$ ] the reference dose, [Adim.] the relative error. The reference dose (RfD) is a toxicological property of the pollutants and represents the estimate of the average daily exposure that does notproduce adverse effects on the human organism during his or her lifetime (ISPRA, 2008).

The health risk determined by the exposition to carcinogenic pollutants is to be calculated as follows (ISPRA, 2008):

$$
\left.R=L A D D^{\prime} S F \text { [Adim. }\right]
$$

where $R$ represents the incremental tumor risk during the study subject's life-time caused by the exposure to the polluter compared to normalexposureconditions, LADD the chronic effective exposition to the polluter, $S F$ [mg kg-1 $\left.\mathrm{d}^{-1}\right]^{-1}$ the carcinogenic potential for polluter dose unit (ISPRA, 2008). Results of Eqs. (7) and (8) are compared with individual and/or cumulative acceptability criteria of health risk for groups of people or pollutant types to evaluate the possible presence of exposure conditions which may have harmful effects on health.

The current standards establish that the acceptable HQ for each toxic substance is 1 while the acceptable individual $R$, for each carcinogenic substance, is equal to $1 \times 10^{-6}$ (Italian Regulation, 2006).

The proposed methodology allows $\mathrm{HQ}$ and $\mathrm{R}$ to be calculated and a comparison to be made between the threshold values for human health starting from a chemical analysis to obtain the concentration of pollutants in the soil. If we start from the threshold values for human health of a particular polluter, and invert the application of the methodology, we can estimate the concentrations in the soil that would represent a risk for human health. These values can be compared with those effectively found from the chemical analysis of the contaminated soils.

Therefore, the described methodology has been inverted to determine the threshold concentrations and has been applied, as example, to the contamination of the agricultural soils by some polycyclic aromatic hydrocarbons.

\section{Areas of study}

The formulated methodology was applied to the agricultural areas of the town of Acerra and of the site of national interest (SNI) of Brindisi, in southern Italy. For these two sites, the results of chemical analysis of soil supplied by competent authorities in their respective territorial agency ARPA (Regional Agency for Environmental Protection) were used for analysis.

\section{Town of Acerra}

The town of Acerra (NA) covers an area of 5400 ha and falls into the SNI Litorale Domitio Flegreo and Agro Aversano. The agricultural areas of Acerra are mostly made up of open fields and greenhouse horticultural activities.

The presence in this area of both authorised and unauthorised landfillsand refuseincinerators hasmeant that, over the years, the environment has been subject to pollution phenomena. The rural territory of Acerra is, in fact, partly interested by light aromatic polycyclic hydrocarboncontamination phenomena (ARPA Campania, 2009). 
Table 2. Comparison between average concentrations with threshold concentrations of contamination (Source: ARPA Campania, 2009).

\begin{tabular}{lcc} 
Substances & Average concentrations in the soil [ $\mathrm{mg} / \mathrm{kg}]$ & $\begin{array}{c}\text { Threshold concentrations of contamination in the } \\
\text { areas to be used as public green spaces [mg//kg] } \\
\text { Table 1/A Annex 5 Part IV Italian Legislative Decree no. } \\
\mathbf{1 5 2 / 0 6} \text { (Italian Regulation, 2006) }\end{array}$ \\
Pyrene & 0.194 & 5 \\
Benzo(a)anthracene & 0.160 & 0.5 \\
\hline Chrysene & 0.164 & 5 \\
Benzo(b)fluorantene & 0.128 & 0.5 \\
\hline Benzo(k)fluoranthene & 0.125 & 0.5 \\
Benzo(a)pyrene & 0.060 & 0.1 \\
\hline Indenopyrene & 0.171 & 0.1 \\
Dibenzo(ah)anthracene & 0.058 & 0.1 \\
\hline Benzo(ghi)perylene & 0.148 & 0.1 \\
Dibenzo(ae)pyrene & 0.034 & 0.1 \\
\hline Dibenzo(ah)pyrene & 0.014 & 0.1 \\
Dibenzo(ai)pyrene & 0.017 & 0.1 \\
\hline Dibenzo(al)pyrene & 0.013 & 0.1
\end{tabular}

\section{Site of national interest of Brindisi}

The SNI of Brindisi occupies a land surface of 5700 ha partly destined to agricultural use. The agricultural areas, mainly vineyards and areas of vegetable and cereal cultivation,are in the southern part of the SNI and receive the pollutants produced by the chemical and industrial plantssouth of the town of Brindisi and by the Federico II thermoelectric carbon centre in Cerano. Metals, chlorinated pesticides and heavy hydrocarbons arecurrently found in the soil.

\section{Results and discussion}

A comparison between the average concentration of PAHs in agricultural soil in Acerra and concentrations provided by Italian standards identified the pollutants that exceed threshold values. Concentrations in excess were determined for indenopyrene and the benzo(ghi)perylene that have, therefore, been subjected to the proposed risk analysis (Table 2).

PAHs can bio-concentrate in the food chain thanks to their considerable solubility in the lipid phasethat promotes transfer from soil to vegetables (Poli and Campello, 1994). In order to explain the methodology adopted, we report the parameters used to estimate the risk associated with the presence of indenopyrene and benzo(ghi)perylene. Indenopyrene has an octanol/water distribution coefficient of 6.65 (ISS-ISPESL, 2009a and 2009b) and, thus, according to the Travis and Arms (1988) [Eq. (1)] model, has a soil-vegetable bio-transfer factor of $5.5 \times 10^{-3}$. Indenopyrene absorption by ingestion is characterised by anRfD of $3.0 \times 10^{-2} \mathrm{mg} \mathrm{kg}^{-1} \mathrm{~d}^{-1}$ and by a carcinogenic potential for dose unit (SF) of $0.7\left[\mathrm{mg} \mathrm{kg}^{-1} \mathrm{~d}^{-1}\right]^{-1}$ (ISS-ISPESL, 2009a and 2009b). Results of the risk analysis according to ingestion of the horticultural products grown in soil contaminated by indenopyrene at a concentration of $0.171 \mathrm{mg} \mathrm{kg}^{-1}$ are reported in Tables 3 and 4 .

Benzo(ghi)perylene has an octanol/water distribution concentration of 6.5 (ISS-ISPESL, 2009a and 2009b) and thus, according to the Travis and Arms model (1988), has a soil-vegetable bio-transfer factor of $6.7 \times 10^{-3}$. Ingestion of benzo(ghi)perylene can have toxic effects (ADD) on human subjects; RfD is $3.0 \times 10^{-2} \mathrm{mg} \mathrm{kg}^{-1} \mathrm{~d}^{-1}$ (ISS-ISPESL, 2009a and $2009 \mathrm{~b})$. Results of the risk analysis linked to the ingestion of horticultural products grown in soil contaminated by benzo(ghi)perylene at a concentration of $0.148 \mathrm{mg} \mathrm{kg}^{-1}$ are reported in Tables 5 and 6 .

The methodology adopted allowed the HQ and the R caused by the
Table 3. Results of proposed methodology for indenopyrene pollutant.

\begin{tabular}{lcc}
\hline Parameter & Value & Units \\
$\mathrm{C}_{\mathrm{v}}$ & $8.4 \mathrm{E}-04$ & $\mathrm{mg} / \mathrm{kg}$ \\
$\mathrm{IR} 1$ & $2.1 \mathrm{E}-01$ & $\mathrm{~kg} / \mathrm{d}$ \\
\hline$\left(\mathrm{C}_{\mathrm{v}} \times \mathrm{IR}\right)$ & $1.8 \mathrm{E}-04$ & $\mathrm{mg} / \mathrm{d}$ \\
ADD adults & $2.4 \mathrm{E}-06$ & $\mathrm{mg} / \mathrm{kg} \mathrm{d}$ \\
\hline ADD children & $1.1 \mathrm{E}-05$ & $\mathrm{mg} / \mathrm{kg} \mathrm{d}$ \\
LADD adults & $8.3 \mathrm{E}-07$ & $\mathrm{mg} / \mathrm{kg} \mathrm{d}$ \\
\hline LADD children & $9.7 \mathrm{E}-07$ & $\mathrm{mg} / \mathrm{kg} \mathrm{d}$ \\
\hline
\end{tabular}

$\mathrm{C}_{v}$, concentration of pollutants; IR, consumption per head for each food category; ADD, average daily dose; LADD, lifetime average daily dose.

Table 4. Danger index and incremental tumour risk indexes related to indenopyrene.

\begin{tabular}{lcc} 
Parameter & Value [Adim.] & Limit value [Adim.] \\
HQ adults & $8.0 \mathrm{E}-05$ & 1 \\
HQ children & $3.8 \mathrm{E}-04$ & 1 \\
\hline R adults & $5.8 \mathrm{E}-07$ & $6.0 \mathrm{E}-06$ \\
R children & $6.8 \mathrm{E}-07$ & $6.0 \mathrm{E}-06$ \\
\hline
\end{tabular}

$\mathrm{HQ}$, danger index; $\mathrm{R}$, incremental tumour risk; Adim., relative error.

Table 5. Results of proposed methodology for benzo(ghi)perylene pollutant.

\begin{tabular}{lcc} 
Parameter & Value & Units \\
$\mathrm{C}_{\mathrm{v}}$ & $8.8 \mathrm{E}-04$ & $\mathrm{mg} / \mathrm{kg}$ \\
$\mathrm{IR} 1$ & $2.1 \mathrm{E}-01$ & $\mathrm{~kg} / \mathrm{d}$ \\
\hline$\left(\mathrm{C}_{\mathrm{V}} \times \mathrm{IR}\right)$ & $1.9 \mathrm{E}-04$ & $\mathrm{mg} / \mathrm{d}$ \\
ADD adults & $2.6 \mathrm{E}-06$ & $\mathrm{mg} / \mathrm{kg} \mathrm{d}$ \\
\hline ADD children & $1.2 \mathrm{E}-05$ & $\mathrm{mg} / \mathrm{Kkg} \mathrm{d}$ \\
\hline
\end{tabular}

$\mathrm{C}_{v}$, concentration of pollutants; IR, consumption per head for each food category; $\mathrm{ADD}$, average daily dose.

Table 6. Danger index and incremental tumour riskindexes related to benzo(ghi)perylene.

\begin{tabular}{lcc} 
Parameter & Value [Adim.] & Limit value [Adim.] \\
HQ adults & $8.5 \mathrm{E}-05$ & 1 \\
HQ children & $4.0 \mathrm{E}-04$ & 1 \\
\hline
\end{tabular}

HQ, danger index; Adim., relative error. 
Table 7. Average concentrations and threshold concentrations of contamination comparison (Source: Nomisma Energia, 2008).

\begin{tabular}{lcc} 
Substances & Average concentrations [mg/kg] & $\begin{array}{l}\text { Threshold concentrations of contamination in the } \\
\text { areas to be used as public green spaces [mg/kg] } \\
\text { Table 1/A Annex 5 Part IV Italian Legislative Decree no. } \\
152 / 06 \text { (Italian Regulation, 2006) }\end{array}$ \\
Arsenic (As) & 21.64 & 20 \\
Beryllium (Be) & 1.81 & 2 \\
\hline Tin $(\mathrm{Sn})$ & 1.13 & 1 \\
Cobalt $(\mathrm{Co})$ & 9.37 & 20 \\
\hline Vanadium $(\mathrm{V})$ & 52.60 & 90 \\
\hline
\end{tabular}

presence of the two pollutants in agricultural soils to be calculated. Total HQ resulting from the ingestion of the agricultural products grown in the examined area and contaminated by inedenopyrene and benzo(ghi)perylene was $1.7 \times 10^{-4}$ for adults and $7.8 \times 10^{-4}$ for children.

The Rvaluelinked to the ingestion of the agricultural products grown in the study area is only linked to the presence of indenopyrene and is $5.8 \times 10^{-7}$ for adults and $6.8 \times 10^{-7}$ for children.

These values are considerably lower than the maximum imposed by the Italian Legislative Decree no. 152/06 (Italian Regulation, 2006) and, therefore, concentrations over the threshold values of contamination byindenopyrene and benzo(ghi)perylene in the soil do not represent a health riskfrom the ingestion of the vegetables grown in the study area.

\section{Analysis of the site of national interest of Brindisi}

The average metal concentrations in the agricultural soil of the SNI of Brindisi were compared to the threshold concentrations of contamination set outin the Italian Legislative no. 152/06 for the areas to be used as public green spaces (Table 7) (Italian Regulation, 2006). Higher arsenic and tin concentrations were found and these, therefore, required risk analysis. However, tin concentrations are close to natural values and are not associated with anthropogenic contamination phenomena; therefore, only arsenic underwent health risk evaluation.

The soil pollution resulting from arsenic is the main source of food contamination (Frankenberger, 2002) and its plant absorption represents a risk for human health (Warren et al., 2003).

The arsenic soil-vegetable bio-transfer coefficient is $3.3 \times 10^{-4}$ for horticultural and cereal cultivation and $2.0 \times 10^{-4}$ for shrubs (Environment Agency, 2009).

Inorganic arsenic ingestion can have both toxic and carcinogenic effects on human health; RfD is $3.0 \times 10^{-4} \mathrm{mg} \mathrm{kg}^{-1} \mathrm{~d}^{-1}$ and SF unit is 1.5 $\left[\mathrm{mg} \mathrm{kg}^{-1} \mathrm{~d}^{-1}\right]^{-1}$ per dose unit.

Results of the risk analysis linked to the ingestion of horticultural products grown in a soil contaminated by arsenic at a concentration of $21.64 \mathrm{mg} \mathrm{kg}^{-1}$ are reported in Tables 8 and 9 .

$\mathrm{HQ}$ is lower than the limit imposed by the Italian Legislative Decree no. 152/06 and, consequently, the consumption of food produced in the agricultural areas of the SNI in Brindisi do not have any toxic effect (Italian Regulation, 2006).

$\mathrm{R}$ from the consumption of agricultural products grown in the study area is $2.1 \times 10^{-5}$ for adults and $2.4 \times 10^{-5}$ for children. The incremental risk value for the ingestion of agricultural products grown in the agricultural areas of the SNI in Brindisi is higher than the accepted limit established by the Italian Legislative Decree no. 152/06 (Italian Regulation, 2006). However, this requires detailed geochemical and mineralogical surveys (i.e. sequential arsenic extraction) aimed at evaluating the arsenic bioavailability in the soil-plant system. In fact, arsenic absorption from agricultural cultivation is not only related to
Table 8. Results of proposed methodology for arsenic pollutants.

\begin{tabular}{lcc} 
Parameter & Value & Units \\
\hline $\mathrm{C}_{\mathrm{v} \text { vegetables and cereals }}$ & $6.3 \mathrm{E}-03$ & $\mathrm{mg} / \mathrm{kg}$ \\
$\mathrm{C}_{\mathrm{v} \text { grape }}$ & $3.8 \mathrm{E}-03$ & $\mathrm{mg} / \mathrm{kg}$ \\
\hline $\mathrm{IR}_{\text {vegetables }}$ & $2.1 \mathrm{E}-01$ & $\mathrm{~kg} / \mathrm{d}$ \\
$\mathrm{IR}_{\text {cereals }}$ & $2.6 \mathrm{E}-01$ & $\mathrm{~kg} / \mathrm{d}$ \\
\hline $\mathrm{IR}_{\text {grape }}$ & $8.5 \mathrm{E}-04$ & $\mathrm{~kg} / \mathrm{d}$ \\
$\left(\mathrm{C}_{\mathrm{v}} \times \mathrm{IR}\right)$ & $2.9 \mathrm{E}-03$ & $\mathrm{mg} / \mathrm{d}$ \\
\hline $\mathrm{ADD}$ adults & $4.0 \mathrm{E}-05$ & $\mathrm{mg} / \mathrm{kg} \mathrm{d}$ \\
ADD children & $1.9 \mathrm{E}-04$ & $\mathrm{mg} / \mathrm{kg} \mathrm{d}$ \\
\hline LADD adults & $1.4 \mathrm{E}-05$ & $\mathrm{mg} / \mathrm{kg} \mathrm{d}$ \\
LADD children & $1.6 \mathrm{E}-05$ & $\mathrm{mg} / \mathrm{kg} \mathrm{d}$ \\
\hline
\end{tabular}

$\mathrm{Cv}$, concentration of pollutants; IR, consumption per-head for each food category; $\mathrm{ADD}$, average daily dose; LADD, lifetime average daily dose.

Table 9. Danger index and incremental tumour riskindexes related to arsenic.

\begin{tabular}{lcc} 
Parameter & Value [Adim.] & Limit value [Adlim.] \\
HQ adults & 0.1 & 1 \\
HQ children & 0.6 & 1 \\
\hline R adults & $2.1 \mathrm{E}-05$ & $6.0 \mathrm{E}-06$ \\
R children & $2.4 \mathrm{E}-05$ & $6.0 \mathrm{E}-06$ \\
\hline
\end{tabular}

$\mathrm{HQ}$, danger index; R, incremental tumour risk, Adim., relative error.

Table 10. Proposal of values of threshold concentration of contamination for some polycyclic aromatic hydrocarbons.

\begin{tabular}{lc} 
Substances & $\begin{array}{c}\text { Threshold concentration } \\
\text { of contamination [ } \mathrm{mg} / \mathrm{Kg}]\end{array}$ \\
Benzo(a)anthracen & 0.10 \\
Benzo(a)pyrene & 1.90 \\
\hline Benzo(b)fluoranthene & 0.20 \\
Benzo(k)fluoranthene & 0.02 \\
\hline Dibenzo(ah)anthracene & 4.10 \\
Dibenzo(ae)pyrene & 4.45 \\
\hline Indenopirene & 0.40
\end{tabular}


the total concentration of the element in the soil, but also to the chemical compounds in which it is present (arsenite, arsenate, arsenic trioxide) and to the chemical-physical characteristics of the soil ( $\mathrm{pH}$, redox potential, particle size) (APAT, 2006).

The health risks related to the presence of arsenic in the agricultural soil should, therefore, be based on the quantity effectively available for the plants and which can be stored in the vegetal tissues (Violante and Branco, 2007). Given this, the farmers of the SNI in Brindisi should be warned to focus their analysis on determining the quantity of arsenic in the vegetal products in order to establish the site-specific soil-plant bio-transfer factor.

\section{Soil threshold concentration of contamination}

The threshold concentration of contamination values of PAHs in the agricultural soils werecalculated using soil-plant bio-transfer factors determined on the basis of the octanol/water distribution coefficient $\left(\mathrm{K}_{\mathrm{ow}}\right)$ (Table 10) and by invertingthe methodological procedure. The calculation was made on the basis of the maximum limit of danger index and incremental risk as established by the Italian Legislative Decree no. 152/06 (Italian Regulation, 2006).

The choice of threshold concentration of contamination determined by the octanol/water distribution coefficients safeguards consumer health without, at the same time, being too restrictive.

The presence in the agricultural soil of the listed pollutants in concentrations higher than those obtained according to the octanol/water distribution coefficient may compromise the safety of the horticultural products. When values higher than those proposed are found in the soil, a random chemical-physical analysis of the agricultural products grown there should be carried out before they are put on the market in order to safeguard consumer health.

\section{Conclusions}

This study stressed the need to consider vegetable ingestion as the way in which human receptors are exposed to the pollutants present in the contaminated agricultural areas. The methodology proposed for the risk analysis of the contaminated agricultural sites allowed the health risks linked to the consumption of agricultural products grown in soils polluted by PAH pollutants to be evaluated. The presence of inorganic substances in the agricultural soil requires further analysis to evaluate their bioavailability. The proposed risk analysis thus appears to be a useful tool to verify and guarantee the health-hygiene safety of the horticultural productions grown in the agricultural areas interested by environmental pollution phenomena. Inverting the risk analysis allowed us to evaluate the concentrations of pollutants compatible with the agricultural activity in the soil. The critical point of the methodology is the determination of soil-plant bio-transfer factor. This is the subject of research relating as it does to individual pollutants, soils properties and specific physiological features of crops. The determination of these values by carrying out in situ analysis on vegetables would reduce the uncertainties related to this type of analytical method.

The proposed methodology, integrated with a validation analysis of the bio-transfer factors, could become an accepted procedure to evaluate a potential health risk. It would offer rigorous quantification of the potential contamination of the agricultural products in favour of consumer health, and define the areas where agricultural activity should be put under strict observation. Furthermore, determination of soilplant bio-transfer factor is one of the key parameters used in mathematical models of harmful substance and/or pesticide dispersion in environmental life cycle analysis of agricultural areas.

\section{References}

ARPA Campania. 2009. Monitoraggio ambientale zona acerrana. Available from: http://www.arpacampania.it/index.asp

ARPA Puglia. 2010a. Relazione sullo stato dell'ambiente. Available from: http://www.arpa.puglia.it/web/guest/arpa_home

ARPA Puglia. 2010b. Traversine ferroviarie dismesse trattate con creosoto. Availble from: http:/www.arpa.puglia.it/web/guest/ rifiuti_ doc_rapp

Beccaloni E., Vanni F., Giovannangeli S., Beccaloni M., Carere M. 2010. Agricultural soils potentially contaminated: risk assessment procedure case studies. Ann. Ist. Super. Sanità. 46:303-8.

Bell R.M. 1992. Higher plant accumulation of organic pollutant from soil, EPA/600/R-92/138. United States Environmental Protection Agency, Cincinnati, OH, USA.

Bosetti, C., Boffetta, P., La Vecchia, C. 2007. Occupational exposures to polycyclic aromatic hydrocarbons, and respiratory and urinary tract cancers: a quantitative review to 2005. Ann. Oncol. 18:431-46.

Brunetti G., Farrag K., Soler-Rovira P., Ferrara M., Nigro F., Senesi N. 2012. The effect of compost and Bacillus licheniformis on the phytoextraction of $\mathrm{Cr}, \mathrm{Cu}, \mathrm{Pb}$ and $\mathrm{Zn}$ by three brassicaceae species from contaminated soils in the Apulia region, Southern Italy. Geoderma. 170:322-30.

Cheng Y., Nathanail P.C. 2009. Generic assessment criteria for human health risk assessment of potentially contaminated land in China. Sci. Total Environ. 408:324-39.

Chiou C.T., Sheng G., Manes M. 2001. A partition-limited model for the plant uptake of organic contaminants from soil and water. Environ. Sci. Technol. 35:1437-44.

Cicero M.R., Scaini F.2010. Valutazione del rischio relativa ad una contaminazione diffusa di un litorale italiano. Ingegneria Ambientale XXXIX:433-8.

CRC Care. 2008. Contaminants and the food chain. Available from: www.crccare.com/research/pn1-3-01.html

D’Aprile L., Calace N., Pirani G. 2006. Sito di Interesse Nazionale di Porto Marghera: studio sui valori di concentrazione dell'arsenico nei suoli ad uso residenziale, A.P.A.T. Available from: http://www. isprambiente.gov.it/files/temi/tec-arsenico-porto-marghera-nov-06.pdf

Di Sante M., Mazzieri F., Pasqualini E. 2009. Assessment of the sanitary and environmental risks posed by a contaminated industrial site. J Hazard. Mater. 171:524-34.

Dowdy D.L, Mckone T.E. 1997. Predicting plant uptake of organic chemicals from soil or air using octanol/water and octanol/air partition ratios and a molecular connectivity index. Environ. Toxicol. Chem. 16:2448-56.

Environment Agency. 2003. Review of the fate and transport of selected contaminants in the soil environment. Draft technical report P5079/TR1.Availble from: http://publications.environment-agency.gov. uk/PDF/SCH00904BIEE-E-E.pdf

Environment Agency. 2006. Evaluation of models for predicting plant uptake of chemicals from soil. Science report SC050021/SR. Availble from: http://www.environment-agency.gov.uk/static/documents/Research/sc050021_2029764.pdf

Environment Agency. 2009. Supplementary information for the derivation of SGV for arsenic. Science report SC050021.Availble from: http://www.environment-agency.gov.uk/static/documents/ Research/SCH00409BPVX-e-e.pdf

European Commission. 2005. Regulation on maximum residue levels of pesticides in or on food and feed of plant and animal origin and amending, Reg. no. 2005/396/EC. In: Official Journal, L 70/1, $16 / 03 / 2005$.

Frankenberger W.T. 2002. Environmental chemistry of arsenic. Marcel Dekker, New York, USA. 
Fryer M.E., Collins C.D. 2003. Model intercomparison for the uptake of organic chemicals by plants. Environ. Sci. Technol. 37:1617-24.

Hung H., Mackay D.1997.A novel and simple model of the uptake of organic chemicals by vegetation from air and soil. Chemosphere. 35:959-77.

IPCS INCHEM (International Programme on Chemical Safety). 1992. Cadmium (Environmental Health Criteria 134). World Health Organization, Geneva, Switzerland. Available from: http://www. inchem.org/documents/ehc/ehc/ehc134.htm

ISPRA (Istituto Superiore per la Ricerca Ambientale). 2008. Criteri metodologici per l'applicazione dell'analisi assoluta di rischio ai siti contaminati. Available from: http://www.isprambiente.gov.it/it/ archivio/eventi/anno-2005/manualirischiositicontaminati

ISS-ISPESL (Istituto Superiore di Sanità - Istituto Superiore per la Prevenzione E la Sicurezza del Lavoro). 2009a. Banca dati ISSISPESL - Proprietà chimico-fisiche dei contaminanti. Available from: http:/www.iss.it/binary/suol/cont/propriet_chim_fis_Banca_ dati_ISS_ISPESL_Maggio_2009.pdf

ISS-ISPESL (Istituto Superiore di Sanità - Istituto Superiore per la Prevenzione E la Sicurezza del Lavoro). 2009b. Banca dati ISSISPESL - Proprietà tossicologiche dei contaminanti. Available from: http:/www.iss.it/binary/suol/cont/prop_toss_Banca_dati_ISS_ISPE SL_Maggio_2009.pdf

Italian Regulation. 2006. Norme in materia ambientale, LD 152/2006. In: Gazzetta Ufficiale no. 88/2006, 3/03/2006.

Khillare P.S., Jyethi D.S., Sarkar S. 2012. Health risk assessment of polycyclic aromatic hydrocarbons and heavy metals via dietary intake of vegetables grown in the vicinity of thermal power plants. Food Chem. Toxicol. 50:164-52.

Kulháneka A., Trapp S., Sismilich M., Janku J., Zimová M. 2005. Cropspecific human exposure assessment for polycyclic aromatic hydrocarbons in Czech soils. Sci. Total Environ. 339:71-80.

Lee, B.M., Shim, G.A. 2007. Dietary exposure estimation of benzo[a]pyrene and cancer risk assessment. J. Toxicol. Environ. Health Part A. 70:1391-4.

McKone T.E. 1993. The precision of QSAR methods for estimating intermedia transfer factors in exposure assessments. SAR QSAR. Environ. Res. 1:41.

McKone T.E., Maddalena R.L. 2007. Plant uptake of organic pollutants from soil: bioconcentration estimates based on models and experiments. Environ. Toxicol. Chem. 12:2494-504.

Nomisma Energia. 2008. Centrali a carbone: suolo e agricoltura. Available from: http://www.nomismaenergia.it/cms/index.php? page $=$ home\&hl=it_IT

Pasetto R., Benedetti M., Fazzo L., Iavarone I., Trinca S. 2007. Impatto sanitario nei siti inquinati: caratterizzazione epidemiologica e ruolo delle ipotesi a priori. In: P. Comba, F. Bianchi, I. Iavarone, R. Pirastu (ed.). Impatto sulla salute dei siti inquinati: metodi e strumenti per la ricerca e le valutazioni. (Rapporti ISTISAN 07/50). Istituto Superiore di Sanità, Roma, Italy.

Paterson S., Mackay D., McFarlane C. 1994. A model of organic chemical uptake by plants from soil and the atmosphere. Environ. Sci. Technol. 28:2259-66.

Petruzzelli G., Pedron F. 2007. Meccanismi di biodisponibilità nel suolo di contaminanti ambientali persistenti. In: P. Comba, F. Bianchi, I. Iavarone, R. Pirastu (ed.). Impatto sulla salute dei siti inquinati: metodi e strumenti per la ricerca e le valutazioni. (Rapporti ISTISAN 07/50). Istituto Superiore di Sanità, Roma, Italy.

Poli A., Campello C. 1994. Contaminazione atmosferica da idrocarburi policiclici aromatici in un'area urbana. Ann. Ig. 6:783-92.

Russo G., Verdiani G. 2012. The health risk of the agricultural products grown in potentially contaminated sites: proposal of an environmental - health risk analysis. Proc. Int. Conf. Agr. Engin., July 8-12, Valencia, Spain.

Ryan J.A., Bell R.M., Davidson J.M., Oconnor G.A. 1988. Plant uptake of non-ionic organic chemicals from soils. Chemosphere.17:2299-323.

Sharma, R.K., Agarwal, M., Marshall, F.M. 2008. Heavy metal (Cu, Zn, $\mathrm{Cd}$ an $\mathrm{Pb}$ ) contamination of vegetables in urban India: a case study in Varanasi. Environ. Pollut. 154:254-63.

Sharma, A.P., Tripathi, B.D. 2009. Assessment of atmospheric PAHs profile through Calotropis gigantean R.Br leaves in the vicinity of an Indian coal-fired power plant. Environ. Monit. Assess. 149:477-82.

Thorne M., Maul P., Robinson P. 2005. The PRISM foodchain modelling software: parameter values for the soil/plant model, QRS-1198A-3, version 1.1. Food Standards Agency, London, UK.

Timidei A., Riganti V. 2009. Determinazione dei valori di concentrazione per l'analisi di rischio in condizioni stazionarie. Ingegneria Ambientale XXXVIII:153-6.

Topp E., Scheunert I., Attar A., Korte F. 1986. Factors affecting the uptake of C-14-labelled organic chemicals by plants from soil. Ecotoxicol. Environ. Safety. 11:219-28.

Trapp S. 2002. Dynamic root uptake model for neutral lipophilic organics. Environ. Toxicol. Chem. 21:203-6.

Trapp S., Cammarano A., Capri E., Reichenberg F., Mayer P. 2007. Diffusion of PAH in potato and carrot slices and application for a potato model. Environ. Sci. Technol. 41:3103-8.

Trapp S., Matthies M. 1995. Generic one-compartment model for uptake of organic chemicals by foliar vegetation. Environ. Sci. Technol. 29:2333-8.

Trapp S., Rasmussen D., Samsøe-Petersen L. 2003. Fruit tree model for uptake of organic compounds from soil. Environ. Res. 14:17-26.

Travis C.C., Arms A.D. 1988. Bioconcentration of organics in beef, milk, and vegetation. Environ. Sci. Technol. 22:271-4.

UNICHIM (Associazione per L'unificazione nel Settore dell'Industria Chimica). 2002. Suoli e falde contaminati - Analisi di rischio sito specifica - Criteri e analisi. Manuale no. 196 Parte I. Available from: http://www.unichim.it/index.php?n=Main.HomePage

US EPA. 1997. Exposure factors handbook. Volume I - General factors, EPA/600/P-95/002Fa. United States Environmental Protection Agency, Cincinnati, OH, USA.

Violante A., Branco A. 2007. Mobilità e fitodisponibilità di arsenico in suoli inquinati. PhD Diss., Università degli Studi di Napoli "Federico II", Italy.

Violante N., Petrucci F., Costantini S., Ciprotti M., D'Ilio S., Senofonte 0. 2007. Monitoraggio biologico dei metalli pesanti. In: P. Comba, F. Bianchi, I. Iavarone, R. Pirastu (ed.). Impatto sulla salute dei siti inquinati: metodi e strumenti per la ricerca e le valutazioni. (Rapporti ISTISAN 07/50). Istituto Superiore di Sanità, Roma, Italy.

Warren G.P., Alloway B.J., Lepp N.W., Singh B., Bochereau F.J.M., Penny C. 2003. Field trials to assess the uptake of arsenic by vegetables from contaminated soils and soil remediation with iron oxides. Sci. Total Environ. 311:19-33.

Yang Z., Zhu L. 2007. Performance of the partition-limited model on predicting ryegrass uptake of polycyclic aromatic hydrocarbons. Chemosphere. 67:402-9.

Yoon E., Park K., Lee H., Yang J.H., Lee C. 2007. Estimation of excess cancer risk on time-weighted lifetime average daily intake of PAHs from food ingestion. Hum. Ecol. Risk Assess.13:669-80.

Zohair A., Salim A.B., Soyibo A.A., Beck A.J. 2006. Residues of polycyclic aromatic hydrocarbons (PAHs), polychlorinated biphenyls (PCBs) and organochlorine pesticides in organically-farmed vegetables. Chemosphere. 63:541-53. 